\title{
Factors That Impact the Psychological Wellbeing of Airborne Isolated Patients
}

Arwa Alghamdi ${ }^{1}$, Amr Albanna ${ }^{2}$, Sama Bukhari ${ }^{1}$, Abeer Nafadi ${ }^{1}$, Shaima Alharazi ${ }^{1}$

1. Medicine, King Saud bin Abdulaziz University for Health Sciences, Jeddah, SAU 2. Medicine, King Saud bin Abdulaziz University for Health Sciences, King Abdullah International Medical Research Center, Jeddah, SAU

Corresponding author: Arwa Alghamdi, arwa.alghamdi1996@gmail.com

\section{Abstract \\ Background}

Lower respiratory tract infections are one of the international leading causes of lost disability-adjusted years, and hence prevention measures, including isolation of high-suspect patients, were established to reduce the risk of transmission. However, isolation can negatively affect the psychological health of isolated patients, leading to anxiety or depression. The study aim was to investigate the association between types of isolation and the levels of anxiety and depression. Other factors that negatively influence the psychological status were identified.

\section{Methods}

This was an observational analytical cross-sectional study. The study included patients aged 18 years and above who had been isolated for at least 48 hours at King Abdulaziz Medical City in Jeddah, in the western region of Saudi Arabia. The data was gathered by interviewing the patients using the Hospital Anxiety and Depression Scale (HADS).

\section{Results}

Among the included 97 isolated patients, 52 (53\%) were men, and 45 (47\%) were women with a mean age of $49.39 \pm 1.87$. Among all participants, $70 \%$ were married, and $72 \%$ had children. The means of anxiety and depression scores were $5.08 \pm 0.39$ and $7.48 \pm 0.40$, respectively. There was no significant association between HADS and types of isolation ( $\mathrm{P}=0.550$ ). Female gender was significantly associated with abnormal HADS ( $36 \%$ vs. $17 \%$; $P=0.040$ ). On the other hand, the frequency of physician follow-up visits reduced the risk for abnormal HADS (22\% vs. $50 \%$; $\mathrm{P}=0.040)$

\section{Conclusion}

Just over one-fourth of the isolated patients had raised anxiety or depression scores. A trend to higher HADS was observed in airborne isolated patients. We found also that females were more susceptible to anxiety and

Review began $11 / 29 / 2020$ Review ended 12/16/2020 Published 12/16/2020

\section{() Copyright 2020}

Alghamdi et al. This is an open access article distributed under the terms of the Creative Commons Attribution License CC-BY 4.0., which permits unrestricted use, distribution, and reproduction in any medium, provided the original author and source are credited. depression, while frequent physician visits improved the psychological wellbeing of isolated patients.

Categories: Internal Medicine, Psychiatry, Infectious Disease Keywords: airborne isolation, isolation, anxiety, depression

\section{Introduction}

Infectious diseases (ID) are defined as illnesses caused by contagious pathogenic microorganisms that can be transmitted from one infected patient to another healthy person [1]. Internationally, the second leading cause of lost disability-adjusted life years is lower respiratory tract infections, and diarrheal diseases and HIV/AIDS are the fourth and fifth, respectively; thus, protocols and prevention measures should be established to reduce their risks [2]. According to the guidelines for isolation precautions in hospitals published by the Centers for Disease Control and Prevention (CDC), patients who are at high suspicion for infectious diseases must start the standard precautions and isolation after the admission immediately until the culture reveals the underlying microorganism if present [3]. Contact isolation precautions are applied for organisms that transmit through direct or indirect contact with the patient or the patient's surroundings. Meanwhile, droplet precautions are intended for pathogens that spread through respiratory secretions. However, for pathogens that remain suspended in the air for long times, airborne precautions are mandatory [4]. Although isolation is indispensable for infection control and to effectively restrain the transmission of the diseases, previous research has reported that it negatively affects the psychological health of isolated patients, leading to anxiety and depression. A systematic review described anxiety and depression as one of the adverse effects of contact isolation [5]. Furthermore, a study conducted in Nigeria showed that prolonged isolation has a significant impact on the psychosocial wellbeing of isolated patients, while a cross-sectional matched cohort study in the Netherlands demonstrated that short-term isolation does not affect anxiety and depression levels [6-7]. Several factors have been suggested as contributors to the 
depressive and anxious states of isolated patients, including separation from their marital partner, the apprehension that people know they have a serious contagious disease, and inability to participate in daily social and economic activities [6]. In conclusion, these studies emphasize that depression and anxiety are common among all types of isolation precautions. However, no study has compared the type of isolation to the extent of anxiety and depression levels yet. Therefore, this study aimed to investigate the association between types of isolation and the levels of depression and anxiety. We expected that airborne isolation has a higher influence on depression and anxiety scores compared to other types of isolation. Moreover, other factors that negatively influence the psychological status of isolated patients were identified.

\section{Materials And Methods}

\section{Study design and setting}

This was an observational analytical cross-sectional study among isolated patients at King Abdulaziz Medical City (KAMC) wards in Jeddah, in the western region of Saudi Arabia.

\section{Sample size and sampling technique}

The estimated sample size required to determine an increase in the prevalence of anxiety from $20 \%$ among patients admitted for non-infectious disorders to $40 \%$ among those admitted to rule out infectious diseases, with a power of $80 \%$ and alpha of 0.05 was around 182 subjects. The required sample size was estimated at the $95 \%$ confidence interval (CI) level with a $50 \%$ response distribution and a margin of error of $\pm 5 \%$. This study followed a non-probability consecutive sampling technique.

\section{Study subjects}

Patients were eligible for the study inclusion criteria if they were aged 18 years and above and had been isolated for at least 48 hours to airborne, contact, or droplet isolation either for suspected or confirmed infection. However, we excluded patients who had previously been diagnosed with any underlying psychiatric disorder and patients on palliative care. Also, patients who could not understand Arabic or English or were unable to communicate with the interviewers, such as intubated and delirious patients, were excluded.

\section{Data collection}

This study was approved by the International Review Board (IRB), King Abdullah International Medical Research Center (KAIMRC; approval SP17/273/3). All the investigators and data collectors have had the "RIGHT CARE, RIGHT NOW" Infection Prevention and Control Training \& Competency Program, a course that prepares health care providers on applying suitable personal precaution equipment to access the isolation rooms with minimal risk of infection. We collected data by interviewing the participants after gaining their consent, and medical files were reviewed to confirm the diagnosis and length of isolation. We gathered data by using two datasheets: the variables and characteristics questionnaire, and the Hospital Anxiety and Depression Scale (HADS) (Figure 1, 2) [8]. 


\section{Cureus}

\section{Variables and Characteristics Questionnaire}

MRN:.............

Type of Isolation:...........

\begin{tabular}{|c|c|c|}
\hline \multicolumn{3}{|c|}{ Demographics } \\
\hline Gender & $\square$ Female. & \\
\hline Age & \multicolumn{2}{|l|}{ Years old. } \\
\hline \multicolumn{3}{|c|}{ Social history } \\
\hline Occupational status & $\begin{array}{l}\square \text { Working. } \quad \square \text { Not wor: } \\
\text { if yes: } \square \text { Governmental. } \\
\square \text { Others: }\end{array}$ & $\begin{array}{l}\text { rking. } \\
\square \text { Private. } \\
\end{array}$ \\
\hline Marital status & $\square$ Married & Iried \\
\hline Do you have children? & $\begin{array}{l}\square \text { No } \\
\text { if yes: } \square 1-2 y \quad \square 3-4 y\end{array}$ & $\begin{array}{l}\square \text { Yes } \\
\square>4 y\end{array}$ \\
\hline Smoker/ secondhand smoke? & $\square$ No & $\square$ Yes \\
\hline \multicolumn{3}{|c|}{ Precautions } \\
\hline $\begin{array}{l}\text { Do the doctors and nurses who enter your room wear } \\
\text { masks and gowns? }\end{array}$ & $\square$ No & $\square$ Yes \\
\hline Do you have a sitter? & $\square$ No & $\square$ Yes \\
\hline Visitors allowed? & $\square$ No & 口Yes \\
\hline Do visitors wear masks? & $\square$ No & $\square$ Yes \\
\hline \multicolumn{3}{|c|}{ The patient's information about the disease (is she/he educated or not) } \\
\hline Do you know your health condition? & $\square$ No & 口Yes \\
\hline Family history of similar illness ? & $\square$ No & $\square$ Yes \\
\hline Do you know your physician? & $\square$ No & $\square$ Yes \\
\hline Do you know your discharge date? & $\square$ No & $\square$ Yes \\
\hline Do you the medications you are taking? & $\square$ No & 口Yes \\
\hline $\begin{array}{l}\text { Have you been admitted before you entered the isola- } \\
\text { tion? }\end{array}$ & $\square$ No & $\square$ Yes \\
\hline Have you been isolated before? & $\square$ No & $\square$ Yes \\
\hline Is your health condition causing depression/anxiety? & $\square$ No & $\square$ Yes \\
\hline Is the isolation causing depression/anxiety? & $\square$ No & $\square$ Yes \\
\hline $\begin{array}{l}\text { Have you ever been diagnosed with depression or } \\
\text { anxiety before? }\end{array}$ & $\square$ No & $\square$ Yes \\
\hline \multicolumn{3}{|c|}{ The patient satisfaction toward the medical care } \\
\hline $\begin{array}{l}\text { I am satisfied with the medical care that have been } \\
\text { provided to you? }\end{array}$ & $\square$ Agree & $\square$ Disagree \\
\hline $\begin{array}{l}\text { I am satisfied with the visiting policy of the hospital? } \\
\text { (timing, No.of visitors...) }\end{array}$ & $\square$ Agree & $\square$ Disagree \\
\hline The isolation is necessary for my health & $\square$ Agree & $\square$ Disagree \\
\hline I am satisfied with the room's cleanliness & $\square$ Agree & $\square$ Disagree \\
\hline $\begin{array}{l}\text { I am satisfied with the frequency with the health } \\
\text { providers follow up }\end{array}$ & $\square$ Agree & $\square$ Disagree \\
\hline Generally, I am satisfied & $\square$ Agree & $\square$ Disagree \\
\hline
\end{tabular}

FIGURE 1: Variables and Characteristics Questionnaire 


\section{Cureus}

Hospital Anxiety and Depression Scale (HADS)

Tick the box beside the reply that is closest to how you have been feeling in the past week Don't take too long over you replies: your immediate is best.

\begin{tabular}{|c|c|c|c|c|c|}
\hline D & A & & D & A & \\
\hline & & I feel tense or 'wound up': & & & I feel as if I am slowed down: \\
\hline & 3 & Most of the time & 3 & & Nearly all the time \\
\hline & 2 & A lot of the time & 2 & & Very often \\
\hline & 1 & From time to time, occasionally & 1 & & Sometimes \\
\hline & 0 & Not at all & 0 & & Not at all \\
\hline & & $\begin{array}{l}\text { I still enjoy the things I used to } \\
\text { enjoy: }\end{array}$ & & & $\begin{array}{l}\text { I get a sort of frightened feeling like } \\
\text { 'butterflies' in the stomach: }\end{array}$ \\
\hline 0 & & Definitely as much & & 0 & Not at all \\
\hline 1 & & Not quite so much & & 1 & Occasionally \\
\hline 2 & & Only a little & & 2 & Quite Often \\
\hline \multirow[t]{7}{*}{3} & & Hardly at all & & 3 & Very Often \\
\hline & & $\begin{array}{l}\text { I get a sort of frightened feeling as if } \\
\text { something awful is about to } \\
\text { happen: }\end{array}$ & & & I have lost interest in my appearance: \\
\hline & 3 & Very definitely and quite badly & 3 & & Definitely \\
\hline & 2 & Yes, but not too badly & 2 & & I don't take as much care as I should \\
\hline & 1 & A little, but it doesn't worry me & 1 & & I may not take quite as much care \\
\hline & 0 & Not at all & 0 & & I take just as much care as ever \\
\hline & & $\begin{array}{l}\text { I can laugh and see the funny side } \\
\text { of things: }\end{array}$ & & & $\begin{array}{l}\text { I feel restless as I have to be on the } \\
\text { move: }\end{array}$ \\
\hline 0 & & As much as I always could & & 3 & Very much indeed \\
\hline 1 & & Not quite so much now & & 2 & Quite a lot \\
\hline 2 & & Definitely not so much now & & 1 & Not very much \\
\hline \multirow[t]{7}{*}{3} & & Not at all & & 0 & Not at all \\
\hline & & $\begin{array}{l}\text { Worrying thoughts go through my } \\
\text { mind: }\end{array}$ & & & $\begin{array}{l}\text { I look forward with enjoyment to } \\
\text { things: }\end{array}$ \\
\hline & 3 & A great deal of the time & 0 & & As much as I ever did \\
\hline & 2 & A lot of the time & 1 & & Rather less than I used to \\
\hline & 1 & From time to time, but not too often & 2 & & Definitely less than I used to \\
\hline & 0 & Only occasionally & 3 & & Hardly at all \\
\hline & & I feel cheerful: & & & I get sudden feelings of panic: \\
\hline 3 & & Not at all & & 3 & Very often indeed \\
\hline 2 & & Not often & & 2 & Quite often \\
\hline 1 & & Sometimes & & 1 & Not very often \\
\hline \multirow[t]{6}{*}{0} & & Most of the time & & 0 & Not at all \\
\hline & & I can sit at ease and feel relaxed: & & & $\begin{array}{l}\text { I can enjoy a good book or radio or TV } \\
\text { program: }\end{array}$ \\
\hline & 0 & Definitely & 0 & & Often \\
\hline & 1 & Usually & 1 & & Sometimes \\
\hline & 2 & Not Often & 2 & & Not often \\
\hline & 3 & Not at all & 3 & & Very seldom \\
\hline
\end{tabular}

Please check you have answered all the questions

Scoring:

Total score: Depression (D) __ Anxiety (A)

$0-7=$ Normal

8-10 = Borderline abnormal (borderline case)

11-21 = Abnormal (case)

FIGURE 2: Hospital Anxiety and Depression Scale (HADS)

The variables and characteristics questionnaire focused on patients' demographics, patients' information about the disease, and patients' overall satisfaction toward the medical care provided. HADS is considered a validated and standardized psychological screening method to assess generalized anxiety in hospitalized patients. It consists of two groups of 14 questions; anxiety and depression separately. Each question was answered with a Likert scoring system: not at all ( 0 points), several days ( 1 point), more than half the days ( 2 points), nearly daily (3 points). The sum of the score is categorized into normal (0-7), borderline (8-10), and a score of (11-21) points out to significant psychological morbidity. In this study, the range (11-21) was considered the cutoff of abnormal results.

\section{Data analysis and statistics}

Microsoft Office Excel software was used for data entry and STATA 12 software (StataCorp., College Station, TX, USA) for data analysis. The proportion and mean for dichotomous and continuous variables, respectively, were measured to describe patients' characteristics. $\chi 2$ test was used for comparative analysis. We considered a P-value of less than 0.05 to be significant.

\section{Results}

Among the 130 subjects interviewed, 97 were included. Fifty-two (53\%) were men and 45 (47\%) were women 


\section{Cureus}

with a mean age of $49.39 \pm 1.87$. Among all participants, $70 \%$ were married and $72 \%$ had children. The means of anxiety and depression scores of the study sample were $5.08 \pm 0.39$ and $7.48 \pm 0.40$, respectively (Table 1 ,

2).

\begin{tabular}{|c|c|c|}
\hline Characteristics & Mean \pm SD & $95 \%$ Confidence Interval \\
\hline Age (year) & $49.39 \pm 1.8$ & $45.6 / \%-53.11 \%$ \\
\hline Anxiety score & $5.08 \pm 0.39$ & $4.30 \%-5.86 \%$ \\
\hline Depression score & $7.48 \pm 0.40$ & $6.69 \%-8.28 \%$ \\
\hline
\end{tabular}

TABLE 1: Characteristics of Participants $(n=97)$

SD: Standard Deveiation

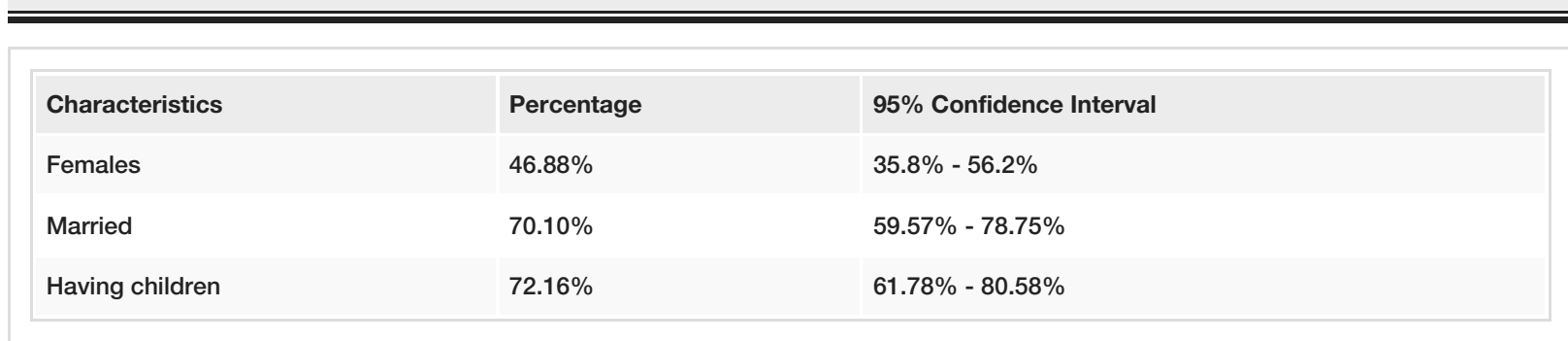

TABLE 2: Socio-demographics of the participants

Figure 3 demonstrates that there was no significant difference between HADS among types of isolation $(\mathrm{P}=$ $0.550)$.

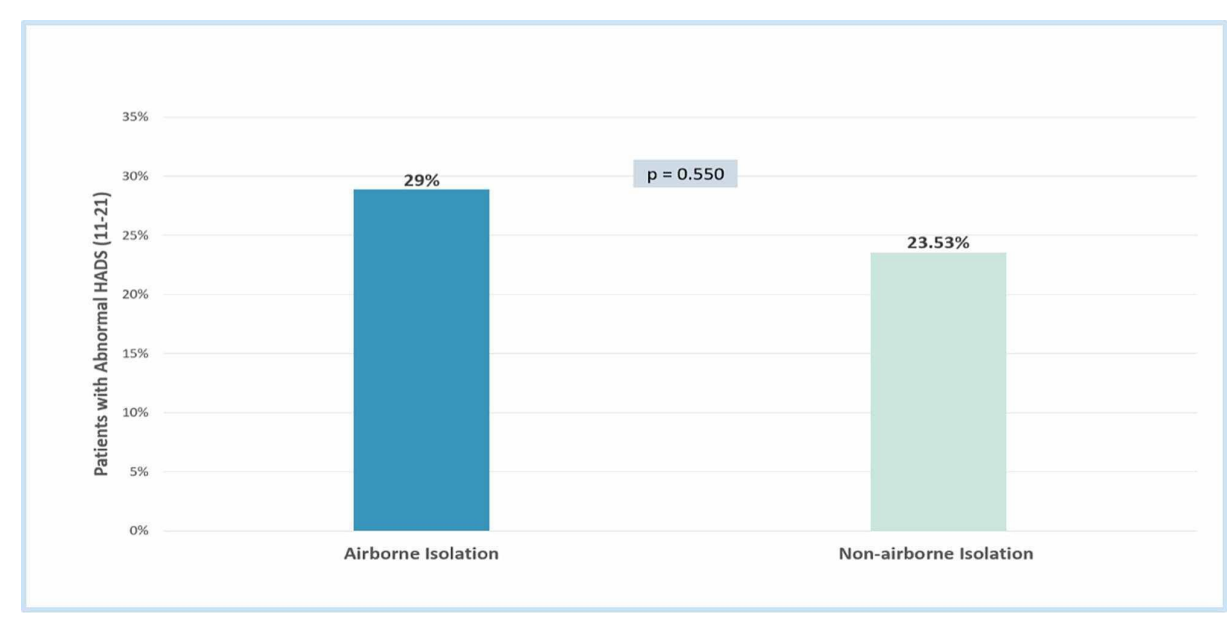

FIGURE 3: Anxiety and depression scores stratified by type of isolation

HADS: Hospital Anxiety and Depression Scale

Among sociodemographic factors, gender was the only factor that showed significant association with HADS, as $36 \%$ of females and $17 \%$ of males had abnormal anxiety or depression scores $(P=0.040)$ (Table 3). 


\section{Cureus}

\begin{tabular}{|c|c|c|c|}
\hline Factor & Total & Abnormal HADS & P-value \\
\hline \multicolumn{4}{|l|}{ Gender } \\
\hline Females & 45 & $16(35.56 \%)$ & \multirow{2}{*}{0.04} \\
\hline Males & 52 & $9(17.31 \%)$ & \\
\hline \multicolumn{4}{|c|}{ Occupational status } \\
\hline Employed & 28 & $5(17.86 \%)$ & \multirow{2}{*}{0.256} \\
\hline Unemployed & 69 & $20(28.99 \%)$ & \\
\hline \multicolumn{4}{|c|}{ Having children } \\
\hline Yes & 70 & $16(22.86 \%)$ & \multirow{2}{*}{0.29} \\
\hline No & 27 & $9(33.33 \%)$ & \\
\hline \multicolumn{4}{|l|}{ Smoking } \\
\hline Yes & 34 & $11(32.35 \%)$ & \multirow{2}{*}{0.297} \\
\hline No & 62 & $14(22.58 \%)$ & \\
\hline \multicolumn{4}{|c|}{ History of previous admission } \\
\hline Yes & 44 & $7(15.91 \%)$ & \multirow{2}{*}{0.058} \\
\hline No & 52 & 17 (32.69\%) & \\
\hline \multicolumn{4}{|c|}{ History of previous isolation } \\
\hline Yes & 37 & $11(29.73 \%)$ & \multirow{2}{*}{0.484} \\
\hline No & 60 & $14(23.33 \%)$ & \\
\hline
\end{tabular}

\section{TABLE 3: Association between participants characteristics and abnormal HADS}

None of the isolation precaution-related factors were significantly associated with HADS; however, there was a trend toward lower HADS among patients who had visitors (Figure 4).

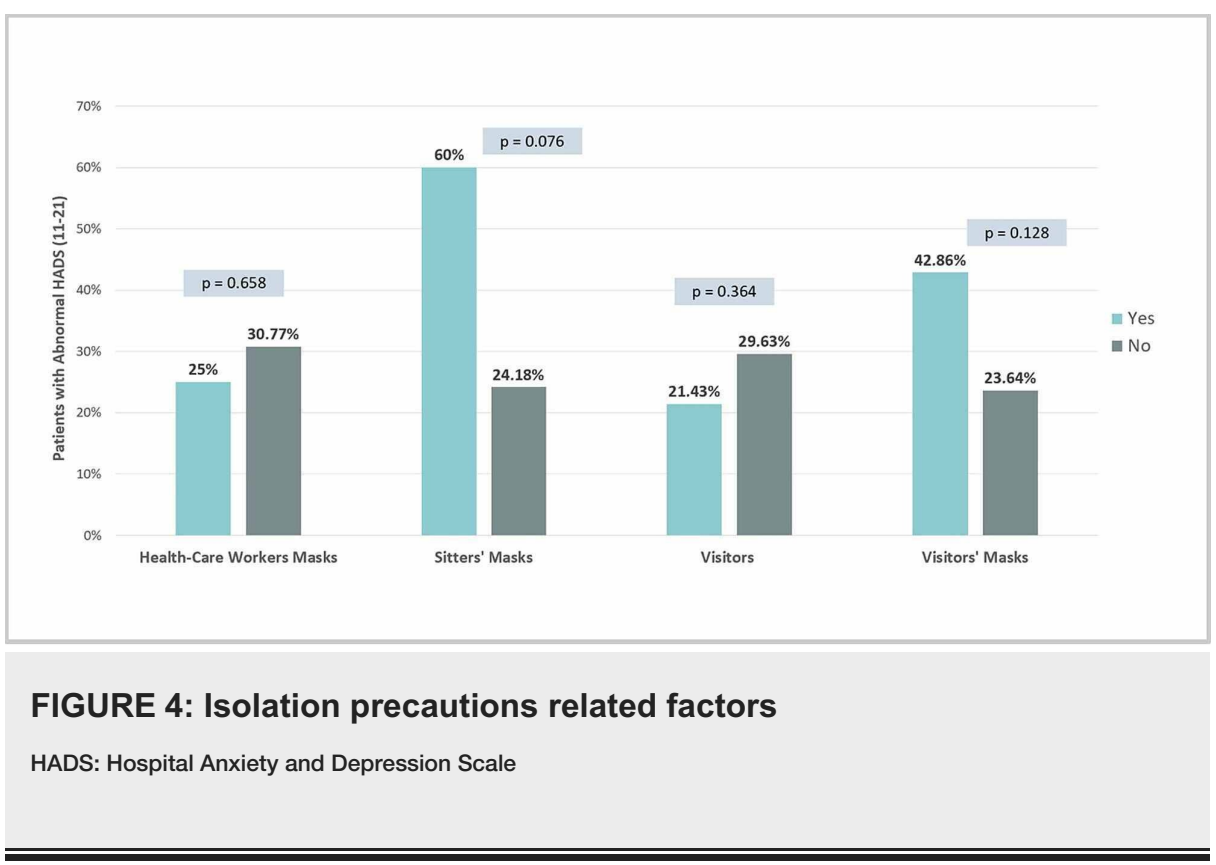




\section{Cureus}

Figure 5 shows that there was no statistically significant association between HADS and patient educationrelated factors, including patients' knowledge about the health condition and physician.

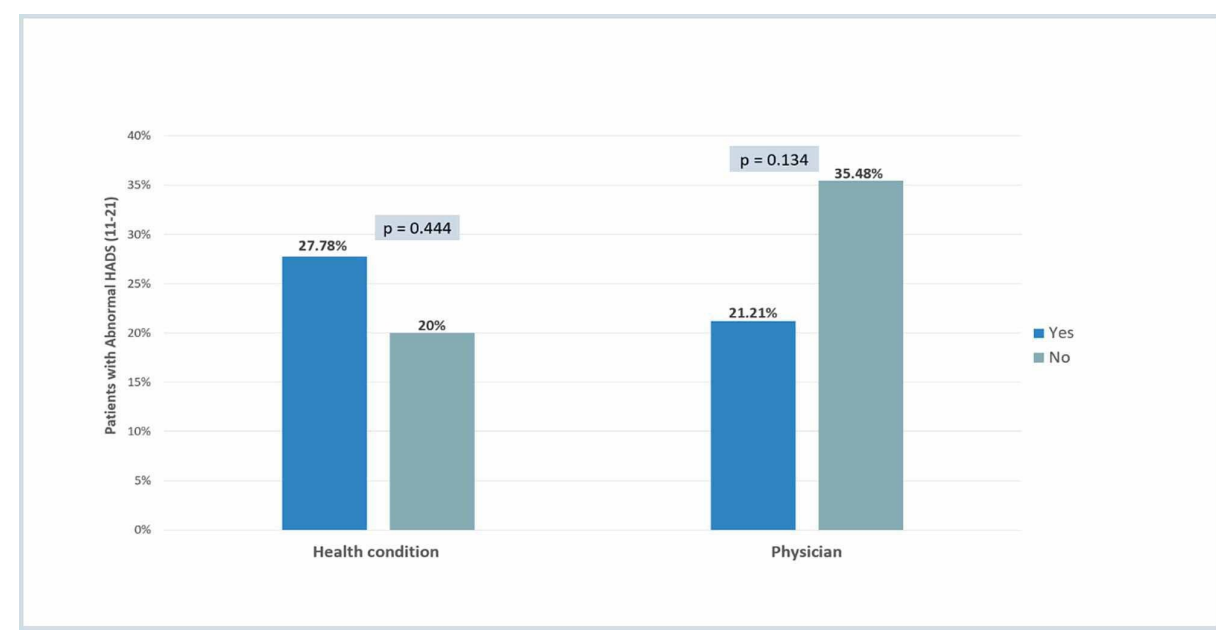

FIGURE 5: Patient education-related factors

HADS: Hospital Anxiety and Depression Scale

Satisfaction towards the frequency of physician follow-up visits significantly reduced the risk of abnormal HADS (22\% vs. $50 \% ; \mathrm{P}=0.040$ ) (Figure 6).

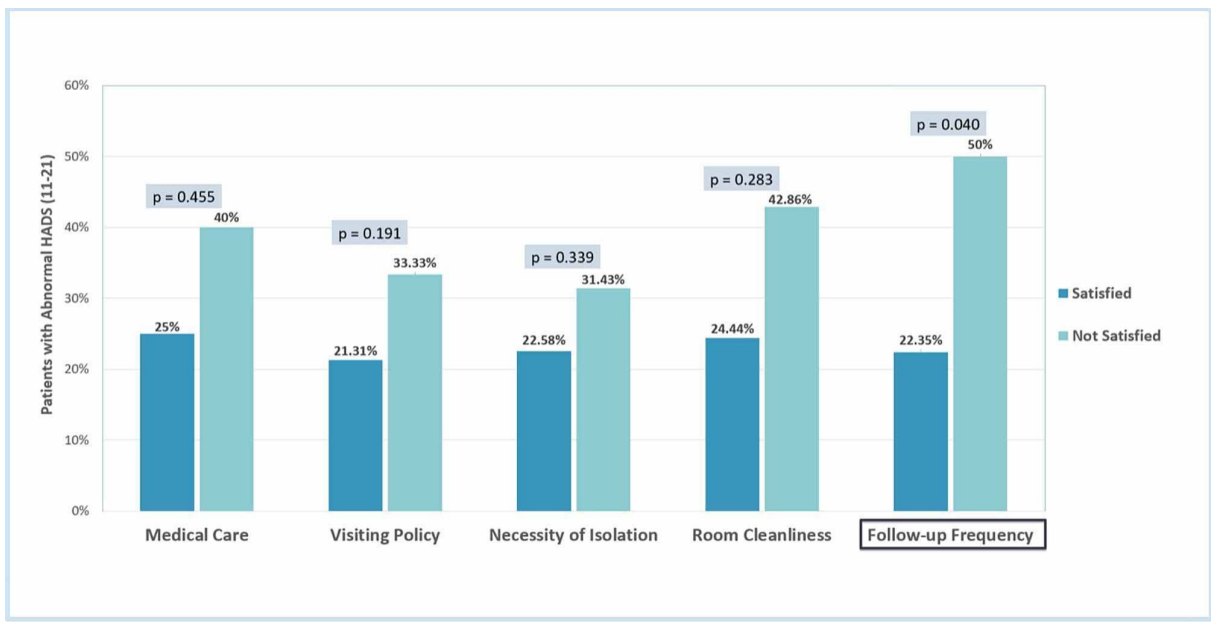

FIGURE 6: Patients satisfaction related factors

HADS: Hospital Anxiety and Depression Scale

\section{Discussion}

This cross-sectional study aimed to investigate the effect of airborne isolation on the levels of anxiety and depression of isolated patients. It is well established that isolation is an effective measurement to control infectious diseases, however, research suggests that it negatively affects the psychological wellbeing of the patients [9-10]. This was demonstrated through our findings as more than one-fourth (26\%) of the participants had raised anxiety or depression scores. A study that was conducted on isolated patients reported significant anxiety in $46 \%$ of the patients using the HADS [9]. The difference between the percentages is attributable to the fact that they considered borderline and abnormal ranges to be significant, while only abnormal ranges were considered in our study. Airborne isolation was expected to have higher anxiety and depression levels. The findings showed a trend to higher anxiety or depression among airborne isolated patients, and that is mainly due to the strict precaution strategies and visiting policy.

Our study demonstrated a substantial relationship between female gender and abnormal anxiety or depression scores. This was supported by a study conducted in Edirne, Turkey in 2012 among contact 
isolated patients, which commented that isolated female patients experienced more psychological morbidity and are more prone to develop depression compared to male patients [10]. Depression and anxiety are experienced differently among opposite genders with various perceptions. According to a psychological study in this interest, women are two times more susceptible to depression than male patients [11]. This higher risk of anxiety and depression among isolated females can be explained due to the separation from their children, which attributes strongly to their emotional state. Correspondingly, we found that subjects who have children had a higher tendency toward abnormal HADS. This may be due to the parents' concerns about directly providing their children's care. This is supported by a Nigerian study, which indicates that subjects were more susceptible to poor psychological wellbeing when their children's needs were provided by others compared to themselves [6].

We also found a trend toward higher anxiety or depression scores in isolated patients who were unemployed. However, this opposes what was observed in the Nigerian study where employed respondents were eight times more likely to experience poor psychosocial wellbeing compared to unemployed respondents [6]. This could be explained by considering the poverty and economic instability that the Nigerian population encounters. Therefore, a greater psychological burden is experienced by these patients when health issues threaten their careers and, thus, socioeconomic status. On the other hand, living in a stable environment economically for employed individuals but with a high workload could contribute to the result mentioned in our study.

Among isolation precaution-related factors, we found a trend toward lower HADS scores when visitors were allowed to enter the patients' rooms. Similarly, a study conducted in the Philippines reports a significant association between low perceived social support and depression among tuberculosis patients [12]. These patients who tend to express higher rates of depression or anxiety, especially when isolated, need the support of their family members and friends to improve psychological wellbeing. Such family support, however, cannot be always guaranteed for airborne isolated patients; therefore, health care providers should consider additional measures to support their psychosocial wellbeing.

Another significant association was observed between patient satisfaction and anxiety and depression levels. Isolated patients who were not satisfied with their physician follow-up frequency had a significant increase in anxiety or depression levels. This was demonstrated as well in a study that assessed the satisfaction among isolated patients compared to non-isolated hospitalized patients, in which they found significant dissatisfaction with health care workers' availability and visits [9]. We hypothesize that patients who do not have the opportunity to convey their concerns to their physicians or do not have answers to their questions regarding their health conditions may also experience more anxiety or depression.

The present study has some limitations. First, the studied population may not adequately represent the general hospital population. This could be due to the limited number of wards and isolation rooms in the studied center, and the exclusion of subjects with language and communication barriers. As a result, this restricted the power of this study to detect more influencing factors.

\section{Conclusions}

Over one-fourth of the isolated patients had abnormal anxiety or depression scores. A trend to higher HADS was observed in airborne isolated patients. We found also that females were more susceptible to anxiety and depression, while frequent physician follow-up visits improved the psychological wellbeing of isolated patients.

We recommend providing a proper psychological assessment for high-risk patients who require isolation. Future longitudinal studies in multiple centers and over longer periods are recommended to evaluate a variety of subjects and assess the influencing factors for each type of isolation individually.

\section{Additional Information}

\section{Disclosures}

Human subjects: Consent was obtained by all participants in this study. King Abdullah International Medical Research Center issued approval SP17/273/3. This study was approved by the Introduction Review Board, King Abdullah International Medical Research Center (KAIMRC). Animal subjects: All authors have confirmed that this study did not involve animal subjects or tissue. Conflicts of interest: In compliance with the ICMJE uniform disclosure form, all authors declare the following: Payment/services info: All authors have declared that no financial support was received from any organization for the submitted work. Financial relationships: All authors have declared that they have no financial relationships at present or within the previous three years with any organizations that might have an interest in the submitted work. Other relationships: All authors have declared that there are no other relationships or activities that could appear to have influenced the submitted work.

\section{References}


1. Barreto ML, Teixeira MG, Carmo EH: Infectious diseases epidemiology. J Epidemiol Community Health. 2006, 60:192-195. 10.1136/jech.2003.011593

2. Hansen V, Oren E, Dennis LK, Brown HE: Infectious disease mortality trends in the United States,1980-2014 . JAMA. 2016, 316:2149-2151. 10.1001/jama.2016.12423

3. Centers for Disease Control and Prevention (US): Guidelines for isolation precautions in hospitals . (2017). Accessed: October 27, 2017: https://wonder.cdc.gov/wonder/prevguid/p0000419/p0000419.asp.

4. Isolation Precautions | Guidelines Library | Infection Control | CDC . (2017). Accessed: October 27, 2017: https://www.cdc.gov/infectioncontrol/guidelines/isolation/index.html.

5. Morgan DJ, Diekema DJ, Sepkowitz K, Perencevich EN: Adverse outcomes associated with contact precautions: a review of the literature. Am J Infect Control. 2009, 37:85-93. 10.1016/j.ajic.2008.04.257

6. Oladimeji O, Ushie BA, Udoh EE, et al.: Psychosocial wellbeing of patients with multidrug resistant tuberculosis voluntarily confined to long-term hospitalisation in Nigeria. BMJ Glob Health. 2016, 1:000006. 10.1136/bmigh-2015-000006

7. Wassenberg M, Severs D, Bonten M: Psychological impact of short-term isolation measures in hospitalized patients. J Hosp Infect. 2010, 75:124-127. 10.1016/j.jhin.2010.01.023

8. Herrmann C: International experiences with the Hospital Anxiety and Depression Scale--a review of validation data and clinical results. J Psychosom Res. 1997, 42:17-41. 10.1016/s0022-3999(96)00216-4

9. Mendoza CL, Domínguez MJ, Fernández CG, Romero-Brioso C, Rodriguez-Bano J: Effects of isolation on patients and staff. Am J Infect Control. 2015, 43:397-399. 10.1016/j.ajic.2015.01.009

10. Findik UY, Ozbaş A, Cavdar I, Erkan T, Topcu SY: Effects of the contact isolation application on anxiety and depression levels of the patients. Int J Nurs Pract. 2012, 18:340-346. 10.1111/j.1440-172X.2012.02049.X

11. Addis, ME: Gender and depression in men. CPSP. 2008, 15:153-168. 10.1111/j.1468-2850.2008.00125.x

12. Masumoto S, Yamamoto T, Ohkado A, Yoshimatsu S, Querri AG, Kamiya Y: Prevalence and associated factors of depressive state among pulmonary tuberculosis patients in Manila, The Philippines. Int J Tuberc Lung Dis. 2014, 18:174-179. 10.5588/ijtld.13.0335 